\title{
THE EFFECT OF DIFFERENT FIXED FACTORS ON CARCASS QUALITY THREE BREED FATTENING PIGS
}

\author{
Č. Radović ${ }^{1}$, M. Petrović ${ }^{2}$, B. Živković ${ }^{1}$, D. Radojković ${ }^{2}$, N. Parunović ${ }^{3}$, \\ N. Stanišić ${ }^{1}$, M. Gogić ${ }^{1}$ \\ ${ }^{1}$ Institute for Animal Husbandry, 11080, Belgrade-Zemun, Republic of Serbia \\ ${ }^{2}$ Faculty of Agriculture, University of Belgrade, 11080, Belgrade - Zemun, Republic of Serbia \\ ${ }^{3}$ Institute of Meat Hygiene and Technology, 11000, Belgrade, Republic of Serbia \\ Corresponding author: cedomirradovic.izs@gmail.com \\ Original scientific paper
}

Abstract: Objective of the paper was to investigate the effect of sire breed and sex of their progeny as well as to study methods for assessment of carcass side quality. Quality of carcass of the progeny was determined according to Rulebook (1985) and share of meat on left carcass sides determined by dissection according to methodology recommended by EU (Commission Regulation EC No 3127/94 and Commission regulation EC No 1197/06) on 84 pigs-progeny of investigated sires. Animals investigated in this study were descendants of dams of $F_{1}$ genotype Swedish Landrace $\mathrm{x}$ Large White (the first one designated is the dam) and two boars Duroc breed ( $n=36$ progeny) and three boars Pietrain breed ( $\mathrm{n}=48$ progeny). Of total number of progeny, 42 animals were male castrates and 42 animals were female. It was established that sire breed influences $(\mathrm{P}<0.01)$ only the fat thickness on the rump (BFTR), whereas sires of Duroc breed influenced ( $\mathrm{P}<0.05$ to $\mathrm{P}<0.001$ ) pre-slaughter mass (PSM), fat thickness in the middle of the back (BFT), share of meat in carcass sides EC No 3127/94 (EC 94) and share of meat in carcass sides EC No 1197/06 (EC 06). Sires within Pietrain breed exhibited effect on $(\mathrm{P}<0.05$ to $\mathrm{P}<0.001)$ BFTR, EC 94 and EC 06. All investigated traits were influenced by sex (gender) $(\mathrm{P}<0.05$ and $\mathrm{P}<0.001)$ except $\mathrm{PSM}$, whereas the effect of genotype $(\mathrm{P}<0.001)$ was present only on PSM. Season of birth influenced only EC 94 and EC $06(\mathrm{P}<0.001)$. By implementation of new methods of assessment of meatiness (EC 94 and EC 06) was determined to have a higher proportion of meat $(13.33 \%$ respectively $16.46 \%$ ) relation to the Rulebook (1985).

Key words: sire breed, boar, genotype, sex, season, assessment method

\section{Introduction}

Purpose of this research was to point out to various methods for establishing of pig meatiness and necessity of more frequent controls of their objectivity and easier changes of it is established that some of the methods and 
formulas used for assessment of meatiness are not objective. By implementation of new methods of assessment of meatiness - Two point method or other modern instrumental methods (e.g. Fat-O-Meater), more objective validation of fatteners is ensured, i.e. producers are paid based on meatiness assessed on slaughter line, compared to current evaluation method valid in Republic of Serbia (Rulebook on quality of slaughtered pigs and categorization of pork, 1985) with which total mass of muscle tissue is determined, without belly-rib part. As a result, meat content determined according to current Rulebook was by 8 to $12 \%$ lower compared to value obtained using Fat-O-Meater (FOM) or dissection according to EU recommended methodology (Walstra and Merkus, 1996). Numerous researches have been carried out on the effect of sire breed, genotype and sex on carcass quality and quality of pig meat (Edwards et al., 2003, Petrović et al., 2004, Jukna and Jukna, 2005, Petrović et al., 2006, Radović et al., 2008, Radović et al., 2009, Radović et al., 2010) and the effect of breed sire, i.e. genotype and sex progeny on quality of pig carcasses and meat has been established.

Also, this research should point out to the importance of evaluation of carcass sides on slaughter line according to S-EUROP classes, i.e. share of muscle tissue, which shall contribute to development of pig breeding, primarily in improvement of genetic potential on farms of individual agricultural producers in Republic of Serbia.

\section{Material and Methods}

Research was carried out on pig farm and in experimental slaughterhouse of the Institute for Animal Husbandry, Belgrade-Zemun. Housing, care and nutrition of animals were in accordance to breeding technology in investigated herd. Animals investigated in this study were descendants of dams of $F_{1}$ genotype Swedish Landrace $\mathrm{x}$ Large White (the first one designated is the dam) and two boars Duroc breed ( $\mathrm{n}=36$ progeny) and three boars Pietrain breed ( $\mathrm{n}=48$ progeny). Besides the sire breed and genotype as fixed factors in the model included season of birth (of total number of progeny, 55 progeny born in the spring and 29 progeny in the autumn) and sex (of total number of progeny, 42 animals were male castrates and 42 animals were females).

Pre-slaughter mass, mass of warm and cold carcasses were measured on adequate scale, accuracy of $\pm 0.5 \mathrm{~kg}$.

Measures for assessment/evaluation of the carcass quality of progeny were taken in the slaughterhouse according to Rulebook (1985) and share of meat on left carcass sides was established by dissection (method recommended by EU) on 84 animals - progeny of investigated sires. Fat thickness was measured in the middle of the back (where fat tissue is the thinnest, area between 13th and 15th vertebrae) and on rump above $m$. gluteus medius where it grows into fat tissue the most. Back fat thickness was measured using steel tape, with accuracy of $\pm 1 \mathrm{~mm}$. For determination of share of meat in carcass sides (JUS 85), based on carried out 
measurings, tables for meaty pigs were used which are integral part of the Rulebook on quality of slaughtered pigs and categorization of pig meat (1985). Share of meat (EC 94 and EC 06) was determined on cooled left carcass sides by method of partial dissection (according to methodology recommended by EUWalstra and Merkus, 1996). Left carcass sides were cut into 12 parts (Figure 1).

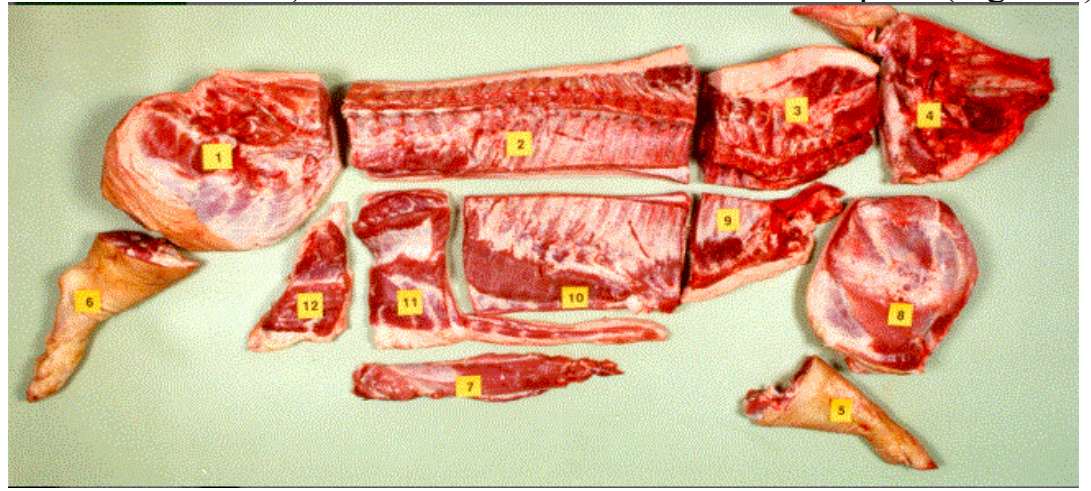

Figure 1. Scheme for cutting of carcass side into 12 parts

Based on quantity of meat in four major parts - leg, shoulder, loin-rump and belly-rib part (skin with subcutaneous tissue, intermuscular fat and bones), which contain $75 \%$ of total musculature mass of carcass side, and mass of tender loin, percentage of meat in carcass sides was calculated using two formulas/equations: 1. Commission Regulation EC No 3127/94 (EC 94)

weight of tender loin + weight of lean (fascia included)

$y=1.3 \times 100 \times \frac{\text { in shoulder, loin, ham and belly }}{\text { weight of tender loin }+ \text { weight of dissected cuts }+ \text { weight of remaining cuts }}$

\section{Commission regulation EC No 1197/06 (EC 06)}

weight of tender loin + weight of lean (fascia included)

$y=0.89 \times 100 \times \frac{\text { in shoulder, loin, ham and belly }}{\text { weight of tender loin }+ \text { weight of dissected cuts }}$

Processing of data was done by implementation of adequate programme, i.e. use of the method of least squares (LSMLMW and MIXMDL-Harvey, 1990) in order to determine the significance $(\mathrm{P}<0.001)$ of systematic influences on quality traits of carcass sides.

Model for analysis of yield and share of meat in carcass sides:

$Y_{i j k l m n}=\mu+F_{i}+O_{j: i}+G_{k}+S_{l}+B_{m}+b_{1}\left(X_{1}-\bar{X}_{l}\right)+\varepsilon_{i j k l m n}$

where: $\mathrm{Y}_{\mathrm{ijk} k \mathrm{mn}}=$ expression of trait in $n$ individual animal, $i$ sire breed, $j$ sire within $i$ breed, $k$ genotype, $l$ sex, $m$ season of birth; $\mu=$ general population average, $F=$ sire 
breed, $O=$ sire within breed, $G=$ genotype, $S=$ sex, $B=$ season of birth, $b_{l}=$ linear regression effect of the warm carcass side mass, $\varepsilon=$ random error.

\section{Result and Discussion}

General population average ( $\mu \pm$ S.E.) and LSMean values of investigated carcass quality traits of progeny, corrected to average mass of warm carcass side, are presented in Table 1. The greatest difference $(\mu)$ in share of meat of $16.46 \%$ was determined between Rulebook (1985) and method EC 06.

Table 1. The effect of sire breed and sex of progeny on quality of carcass sides (LSMean values, $M T P=86.71 \mathrm{~kg}$ )

\begin{tabular}{|c|c|c|c|c|c|c|c|}
\hline \multicolumn{2}{|c|}{ Variation source } & $\mathrm{PSM}^{3)}, \mathrm{kg}$ & $\begin{array}{c}\text { BFT, } \\
\mathrm{mm}\end{array}$ & $\begin{array}{c}\text { BFTR, } \\
\mathrm{mm}\end{array}$ & $\begin{array}{c}\text { JUS } \\
85, \% \\
\end{array}$ & $\begin{array}{c}\text { EC 94, } \\
\%\end{array}$ & $\begin{array}{c}\text { EC 06, } \\
\%\end{array}$ \\
\hline \multicolumn{2}{|c|}{$\begin{array}{l}\mu \\
\pm \text { S.E. }\end{array}$} & $\begin{array}{c}106.32 \\
\pm 0.50\end{array}$ & $\begin{array}{l}15.99 \\
\pm 0.86\end{array}$ & $\begin{array}{l}16.13 \\
\pm 0.63\end{array}$ & $\begin{array}{l}44.23 \\
\pm 0.24\end{array}$ & $\begin{array}{l}57.56 \\
\pm 0.70\end{array}$ & $\begin{array}{l}60.69 \\
\pm 0.69\end{array}$ \\
\hline \multirow[t]{2}{*}{$\begin{array}{l}\text { Sire breed } \\
\text { Duroc }\end{array}$} & $\begin{array}{c}\text { Sire No } \\
1 \\
2\end{array}$ & $\begin{array}{l}109.84 \\
103.52\end{array}$ & $\begin{array}{l}18.83 \\
12.40\end{array}$ & $\begin{array}{l}16.31 \\
13.52\end{array}$ & $\begin{array}{l}43.76 \\
45.23\end{array}$ & $\begin{array}{l}53.65 \\
60.13\end{array}$ & $\begin{array}{l}58.07 \\
63.19\end{array}$ \\
\hline & Average & 106.68 & 15.62 & 14.91 & 44.50 & 56.89 & 60.63 \\
\hline \multirow[t]{2}{*}{$\begin{array}{l}\text { Sire breed } \\
\text { Pietrain }\end{array}$} & $\begin{array}{c}\text { Sire No } \\
3 \\
4 \\
5\end{array}$ & $\begin{array}{l}105.74 \\
106.20 \\
105.96\end{array}$ & $\begin{array}{l}17.13 \\
15.49 \\
16.47\end{array}$ & $\begin{array}{l}14.30 \\
18.65 \\
19.11\end{array}$ & $\begin{array}{l}44.30 \\
44.01 \\
43.58\end{array}$ & $\begin{array}{l}54.31 \\
62.67 \\
57.69\end{array}$ & $\begin{array}{l}58.15 \\
63.73 \\
60.41\end{array}$ \\
\hline & Average & 105.96 & 16.36 & 17.36 & 43.97 & 58.22 & 60.76 \\
\hline \multicolumn{2}{|c|}{$\begin{array}{l}\text { Genotype } \\
\text { क } \\
+ \text { SLxLW x }{ }^{\lambda} \mathrm{D} \\
\text { o SLxLW x }{ }^{\lambda} \mathrm{P}\end{array}$} & $\begin{array}{l}106.07 \\
108.33\end{array}$ & $\begin{array}{l}16.92 \\
17.35\end{array}$ & $\begin{array}{l}16.21 \\
15.49\end{array}$ & $\begin{array}{l}44.04 \\
44.13\end{array}$ & $\begin{array}{l}56.22 \\
54.97\end{array}$ & $\begin{array}{l}59.40 \\
59.14\end{array}$ \\
\hline & $\begin{array}{l}\mathrm{x} \\
\text { strated } \\
\text { ale }\end{array}$ & $\begin{array}{l}106.68 \\
105.96\end{array}$ & $\begin{array}{l}17.24 \\
14.74\end{array}$ & $\begin{array}{l}16.82 \\
15.45\end{array}$ & $\begin{array}{l}43.92 \\
44.55\end{array}$ & $\begin{array}{l}56.23 \\
58.89\end{array}$ & $\begin{array}{l}59.37 \\
62.02\end{array}$ \\
\hline \multicolumn{2}{|c|}{$\begin{array}{l}\text { Spring } \\
\text { Autumn }\end{array}$} & $\begin{array}{l}107.13 \\
105.51\end{array}$ & $\begin{array}{l}16.76 \\
15.22 \\
\end{array}$ & $\begin{array}{l}17.16 \\
15.11 \\
\end{array}$ & $\begin{array}{l}43.93 \\
44.53 \\
\end{array}$ & $\begin{array}{l}55.02 \\
60.09 \\
\end{array}$ & $\begin{array}{l}57.78 \\
63.61 \\
\end{array}$ \\
\hline \multicolumn{2}{|c|}{$\mathrm{MTP}^{2)}(\mathrm{b})$} & 1.130 & 0.175 & 0.160 & -0.016 & -0.090 & -0.095 \\
\hline
\end{tabular}

${ }^{1)}$ Sire No-sires within the breed, MTP $^{2)}$ (b)- linear effect of warm carcass side mass; ${ }^{3)}$ PSM- preslaughter mass, BFT- fat thickness in the middle of the back, BFTR- fat thickness on the rump, JUS 85-share of meat in carcass sides (SL SFRJ 1985), EC 94-share of meat in carcass sides (EC No 3127/94), EC 06-share of meat in carcass sides (EC No 1197/06)

Results of the research and effects of included fixed factors into model on investigated traits are presented in Table 1 . The thinnest back fat was determined in progeny of sires of Duroc breed BFT $=15.62 \mathrm{~mm}$ and BFTR $=14.91 \mathrm{~mm}$ (and within breed Duroc sire No. $2 \mathrm{BTF}=12.40 \mathrm{~mm}$ and $\mathrm{BTFR}=13.52 \mathrm{~mm}$ ), and the thickest fat in the middle of the back $(18.83 \mathrm{~mm})$ was established in progeny of Duroc sires No. 1, and on rump $(19.11 \mathrm{~mm})$ in progeny of Pietrain sire No.5. The least 
established difference for meatiness (12.39\%) was between JUS 85 and EC 94 in case of progeny of sires Duroc. The highest share of meat $60.76 \%$ (EC 06) and the lowest $43.97 \%$ (JUS 85) were established in progeny of Pietrain sires. Established difference in stated breeds between EC 94 and EC 06 methods used for assessment of meatiness was $3.74 \%$ respectively $2.54 \%$. Compared to our research, Radović et al. (2010), for the same sets of parents, similar to our study, established that offspring of Pietrain breed sires had less value of BFT $(16.07 \mathrm{~mm})$ and BFTR $(15.96 \mathrm{~mm})$, while the descendants of Duroc sires had greater value of BFT $(16.65: 15.62 \mathrm{~mm})$ and almost identical values of BFTR $(14.63: 14.91 \mathrm{~mm})$. In the study, the values of the share of meat in sires of Duroc and Pietrain breeds in research by Radović et al. (2010) were lower EC 94 (-2.13 and -1.90\%) and EC 06 $(-1.64$ and $-1.46 \%)$ compared to our results. Edwards et al. (2003) have also investigated the effect of sire breed (Duroc and Pietrain) that mated with sows of Yorkshire breed and Yorkshire x Landrace F1 on carcass quality traits of offspring, and established that offspring of Duroc breed sires had thicker back fat (measured on the back at the level of the first and the last rib, and last lumbar vertebra above the 10th rib) compared to the offspring of Pietrain breed sires which is in contradiction with our results. In their study the influence $(\mathrm{P}<0.01$ and $\mathrm{P}<0.001)$ of sire breed for all of these traits except for fat thickness at the level of the last rib was established, whereas in our study (Table 2) the effect of sire breed on BFRT $(\mathrm{P}<0.01)$ was determined, but not on the BFT $(\mathrm{P}>0.05)$.

Table 2. Statistical significance (level of significance) of effects included in the model for studied traits

\begin{tabular}{|c|c|c|c|c|c|c|}
\hline $\begin{array}{c}\text { Variation source } \\
(\mathrm{effect})\end{array}$ & PSM $^{1)}$ & BFT & BFTR & $\begin{array}{c}\text { JUS } \\
85\end{array}$ & $\begin{array}{c}\text { EC } \\
94\end{array}$ & $\begin{array}{c}\text { EC } \\
06\end{array}$ \\
\hline Sire breed & NS $^{3)}$ & NS & $* *$ & NS & NS & NS \\
\hline S:Duroc & $* * *$ & $*$ & NS & NS & $* *$ & $*$ \\
\hline S:Pietrain & NS & NS & $*$ & NS & $* * *$ & $* *$ \\
\hline Genotype & $* * *$ & NS & NS & NS & NS & NS \\
\hline Sex & NS & $* *$ & $*$ & $*$ & $* * *$ & $* * *$ \\
\hline Season of birth & NS & NS & NS & NS & $* * *$ & $* * *$ \\
\hline MTP (b) & $* * *$ & $*$ & $* *$ & NS & NS & NS \\
\hline $\mathrm{R}^{2}$ & 0.975 & 0.251 & 0.610 & 0.251 & 0.396 & 0.390 \\
\hline
\end{tabular}

1) S:Duroc-sires within the breed Duroc, S:Pietrain-sires within the breed Pietrain, MTP (b)- linear effect of warm carcass side mass, $\mathrm{R}^{2}$ - coefficient of determination; ${ }^{2)} \mathrm{PSM}$ - pre-slaughter mass, BFT- fat thickness in the middle of the back, BFTR- fat thickness on the rump, JUS 85-share of meat in carcass sides (SL SFRJ 1985), EC 94-share of meat in carcass sides (EC No 3127/94), EC 06 -share of meat in carcass sides (EC No $1197 / 06$ ); ${ }^{3)} \mathrm{NS}=\mathrm{P}>0.05 ; \quad *=\mathrm{P}<0.05 ; \quad * *=\mathrm{P}<0.01$; $* * *=\mathrm{P}<0.001$

In accordance with our results for the three-breed crosses [(Swedish Landrace x Swedish Yorkshire) x Hampshire] Olson et al. (2003) have found $(\mathrm{P}<0.001)$ higher estimated lean meat in female fatteners $(58.8: 56.2 \%)$ and thinner 
bacon $(11.3: 14.7 \mathrm{~mm})$ compared to the castrated male animals. However, the opposite results were obtained by Kušec et al. (2006). They found that castrated males have a higher proportion of meat determined by dissection $(52.99 \%)$ compared to female animals (51.16\%) and at the same time, no significant difference $(\mathrm{P}>0.05)$ was established between the sexes. Research results of Šimek et al. (2004) and Radović et al. (2010) for investigated sex of progeny demonstrated effect $(\mathrm{P}<0.01 ; \mathrm{P}<0.001)$ on all investigated traits and methods of assessment of meatiness, except on pre-slaughter mass $(\mathrm{P}>0.05)$ that are in accordance with our result. Latorre et al. $(2003,2004)$ stated that castrates had higher $(\mathrm{P} \leq 0.001)$ back fat tissue above the gluteus medius compared to the carcass of gilts which according to our results was only at the lower level of significance $(\mathrm{P}<0.05)$, while the percentage of muscle tissue in castrates $(\mathrm{P} \leq 0.01)$ was lower than in gilts. Also, in our study, a lower percentage of muscle tissue (JUS 85, EC 94 and EC 06) was identified for castrates compared to the female animals, except that in our study a highly significant difference $(\mathrm{P}<0.001)$ between female and male castrated animals was established.

\section{Conclusions}

By implementation of new methods of assessment of meatiness (EC 94 and EC 06) was determined to have a higher proportion of meat (13.33 respectively $16.46 \%$ ) relation to the Rulebook (1985). This research indicates the necessity of changing of current method for establishing of meatiness of pigs in Republic of Serbia. It was established that sire breed influenced only BFTR $(\mathrm{P}<0.01)$, while sires within Duroc breed influenced $(\mathrm{P}<0.05$ to $\mathrm{P}<0.001)$ PSM, BFT, EC 94 and EC 06. Sires within Pietrain breed exhibited influence $(\mathrm{P}<0.05$ to $\mathrm{P}<0.001)$ on BFTR, EC 94 and EC 06. The effect of sex (gender) on all traits was determined $(\mathrm{P}<0.05$ and $\mathrm{P}<0.001)$ except $\mathrm{PSM}$, whereas the effect of genotype was exhibited $(\mathrm{P}<0.001)$ only on PSM. Season of birth influenced only EC 94 and EC 06 $(\mathrm{P}<0.001)$.

\section{Acknowledgements}

Research was financed by the Ministry of Education, Science and Technological Development of the Republic of Serbia, project TR31081.

\section{Uticaj različitih fiksnih faktora na kvalitet polutki trorasnih tovljenika}

Č. Radović, M. Petrović, B. Živković, D. Radojković, N. Parunović, N. Stanišić, M. Gogić 


\section{Rezime}

Predmet istraživanja ove studije je utvrđivanje uticaj rase očeva, očeva, genotipa, pola i sezone rođenja na fenotipsku i genetsku varijabilnost pojedinih osobina kvaliteta polutki trorasnih hibrida. Utvrđeno je da između očeva dve rase (durok : pijetren) postoji mala razlika za procenjenu mesnatost (+0.53\% JUS 85; $1.33 \%$ EC 94 i -0.13\% EC 06) potomaka koja nije statistički značajna ( $>0.05)$. Posmatrajući očeve unutar rase durok utvrđena razlika između očeva br. 1 i 2 za procenjenu mesnatost potomaka EC 06 iznosila je 5.12\% $(\mathrm{P}<0.05)$. Veća razlika (od 5.58\%; $\mathrm{P}<0.01$ ) za procenjenu mesnatost EC 06 utvrđena je između potomaka oca br. 3 i 4 rase pijetren. Između ispitivanih trorasnih genotipova nisu utvrđene statistički značajne razlike $(\mathrm{P}>0.05)$ za debljinu slanine i procenjenu mesnatost. Ženska grla su imala tanje slanine ( $-2.5 \mathrm{~mm}$ BFT i $-1.37 \mathrm{~mm}$ BFTR) u odnosu na muška kastrirana grla samim tim imala su veće vrednosti za procenjenu mesnatost $(+0.63 \%$ JUS $85 ;+2.66 \%$ EC $94 \mathrm{i}+2.65 \%$ EC 06$)$. Potomci ispitivanih očeva koji su rođeni u jesen imali su veću procenjenu mesnatost $(+0.6 \%$ JUS $85 ;+5.07 \%$ EC $94 \mathrm{i}+5.83 \%$ EC 06) i tanju slaninu (-1.54 mm BFT i $-2.05 \mathrm{~mm}$ BFTR) u odnosu na grla koja su rođena u proleće. Sezona rođenja uticala je $(\mathrm{P}<0.001)$ na procenjenu mesnatost EC 94 i EC 06.

\section{References}

++ (1985): Rulebook on quality of slaughtered pigs and categorization of pig meat, Službeni list SFRJ, 2, 20-30.

++ (1994): Commission Regulation (EC) No 3127/94 of 20 December 1994 amending regulation (EEC) No 2967/85 laying down detailed rules for the application of the Community scale for grading pig carcasses. Official Journal of the European Union, L 330, 21/12/1994, 43-44.

++ (2006): Commission Regulation (EC) No 1197/2006 of 7 August 2006 amending regulation (EEC) No 2967/85 laying down detailed rules for the application of the Community scale for grading pig carcasses. Official Journal of the European Union, 49, L 217, 8/8/2006, 6-7.

EDWARDS B. D., BATES O.R., OSBURN N.W. (2003): Evaluation of Duroc- vs. Pietrain-sired pigs for carcass and meat quality measures. Journal of Animal Science, 81, 1895-1899.

JUKNA V., JUKNA C. (2005): The comparable estimation of meat quality of pigs breeds and their combinations in Lithuania. Biotechnology in Animal Husbandry 21, 5-6, 175-179

HARVEY R.W. (1990): User's guide for LSMLMW and MIXMDL. Ver. PC-2, 191. 
KUŠEC G., ĐURKIN I., PETRIČEVIĆ A., KRALIK G., MALTAR Z. (2006): Utjecaj spola na distribuciju tkiva u svinjskim polovicama, Krmiva, 48, 131-142. LATORRE A. M., LÁZARO R., GRACIA I. M., NIETO M., MATEOS G. G. (2003): Effect of sex and terminal sire genotype on performance, carcass characteristics, and meat quality of pigs slaughtered at $117 \mathrm{~kg}$ body weight. Meat Science, 65, 4, 1369-1377.

LATORRE A. M., R. LA ' ZARO, D. G. VALENCIA, P. MEDEL, G. G. MATEOS (2004): The effects of gender and slaughter weight on the growth performance, carcass traits, and meat quality characteristics of heavy pigs. Journal of Animal Science, 82, 526-533.

OLSSON V., ANDERSSONB K., HANSSONA I., LUNDSTROM K. (2003): Differences in meat quality between organically and conventionally produced pigs. Meat Science, 64, 287-297.

PETROVIĆ M., ŽIVKOVIĆ B., MIGDAL W., RADOJKOVIĆ D., RADOVIĆ Č., KOSOVAC O. (2004): The effect genetic and non-genetic factors on the quality of carcass and meat of pigs. International Conference "Pig and Poultry meat safety and quality-genetic and non-genetic factors", Krakow, 14-15october, 72.

PETROVIĆ M., PUŠIĆ M., RADOJKOVIĆ D., MIJATOVIĆ M., RADOVIĆ Č., ŽIVKOVIĆ B. (2006): Fenotipska i genetska varijabilnost osobina kvaliteta polutki i mesa. Biotechnology in Animal Husbandry 22, 5-6, 1-10.

RADOVIĆ Č., PETROVIĆ M., ŽIVKOVIĆ B., KOSOVAC O., PARUNOVIĆ N. (2008): The effect of different fixed factors on quality traits of pig carcass. Journal of Mountain Agriculture on the Balkans, 11, 4, 649-659.

RADOVIĆ Č., PETROVIĆ M., KOSOVAC O., STANIŠIĆ N., RADOJKOVIĆ D., MIJATOVIĆ M. (2009): The effect of different fixed factors on pig carcass quality and meat traits. Biotechnology in Animal Husbandry, 25, 3-4, 189-196.

RADOVIĆ Č., PETROVIĆ M., ŽIVKOVIĆ B., KOSOVAC O., STANIŠIĆ N., PARUNOVIĆ N., SAVIĆ R. (2010): The effect of sire breed and sex of progeny on meatiness of pigs and methods of evaluation of carcass side quality. Bulgarian Journal of Animal Science, XLVI, 1, 124-129.

ŠIMEK J., GROLICHOVÁ M., STEINHAUSEROVÁ I., STEINHAUSER L. (2004): Carcass and meat quality of selected final hybrids of pigs in the Czech Republic. Meat Science, 66, 383-386.

WALSTRA P., MERKUS G.S.M. (1996): Procedure for assessment of the lean meat percentage as a consequence of the new EU reference dissection method in pig carcass classification. Report ID-DLO 96.014, March, 22. 